\title{
The effect of ozone on the biodegradation of $17 \alpha$-ethinylestradiol and sulfamethoxazole by mixed bacterial cultures
}

\author{
Simone Larcher • Viviane Yargeau
}

Received: 3 February 2012 /Revised: 7 March 2012 /Accepted: 23 March 2012 /Published online: 26 April 2012

(C) Springer-Verlag 2012

\begin{abstract}
The potential development of antibacterial resistance and endocrine disruption has led to increased research investigating the removal of contaminants from wastewater (WW) such as sulfamethoxazole (SMX) and $17 \alpha$ ethinylestradiol (EE2). These compounds react quickly with ozone $\left(\mathrm{O}_{3}\right)$, thus ozonation during WW treatment may result in their complete removal. Also, $\mathrm{O}_{3}$ has demonstrated the ability to increase the biodegradability of WW and certain pharmaceuticals, suggesting its potential as a pretreatment to activated sludge (AS, biological treatment). The objective of this study was to determine whether ozonation, conducted at doses lower than commonly applied to treated WW, would lead to an increased biodegradability of SMX and EE2. The results show that after ozonation performed at lab-scale the bacterial mixtures removed $5 \%$ to $40 \%$ more SMX; however, $2 \%$ to $23 \%$ less EE2 was removed, which was attributed to the observed preferential degradation of a byproduct of EE2 ozonation. These results suggest that although ozonation, used as a pretreatment, was shown in literature to increase the overall biodegradability of AS as well as some specific antibiotic compounds and a blood lipid regulator, the potential for increased removal of pharmaceuticals seems to be compound-dependent and cannot yet be extrapolated to this entire class of compounds.
\end{abstract}

Keywords Ozone $\cdot$ Sulfamethoxazole $17 \alpha$-ethinylestradiol $\cdot$ Biodegradation $\cdot$ Mixed bacteria

S. Larcher $\cdot$ V. Yargeau $(\bowtie)$

Department of Chemical Engineering, McGill University, 3610 University Street,

Montréal, Québec, Canada H3A 2B2

e-mail: viviane.yargeau@mcgill.ca

\section{Introduction}

As a result of the common use of pharmaceutical compounds worldwide, their presence in the aquatic environment has become an issue of increased interest and research. Antibiotic compounds represent one of the main concerns due to the potential development of antibacterial resistances in bacteria present in the environment and in biological wastewater (WW) treatment (activated sludge, AS) (Andersson 2003; Reinthaler et al. 2003; Volkmann et al. 2004). Estrogenic compounds represent another very important concern due to their effect on the fertility and development (endocrine disruption) of aquatic organisms at part per trillion (nanogram per liter) concentrations (Jobling et al. 2006; Vajda et al. 2008). Two of the most popularly prescribed drugs in these categories are sulfamethoxazole (SMX) and $17 \alpha$-ethinylestradiol (EE2) (Cavallucci 2007). SMX is a synthetic antibiotic that has been detected in WWs at up to microgram per liter levels and surface waters at nanogram per liter levels (Joss et al. 2005; Kolpin et al. 2002; Miège et al. 2009), while the synthetic estrogen EE2 (the main ingredient in oral contraceptive pills) has been detected at nanogram per liter levels in both surface waters and WWs (Kolpin et al. 2002; Miège et al. 2009; Ternes 1998). This is due to disposal and excretion, which has been estimated to reach from $50 \%$ up to $90 \%$ of the original ingested amount (Johnson and Williams 2004; Kümmerer 2009a, b) as well as incomplete removal during conventional WW treatment (Miège et al. 2009; Ternes et al. 2006).

The use of ozone $\left(\mathrm{O}_{3}\right)$ as an advanced WW treatment to increase the removal of pharmaceuticals has been the focus of numerous studies due to its ability to oxidize compounds with structures containing carbon-carbon double bonds, aromatics, hydroxyl, and amino groups (Huber et al. 2003; Ternes et al. 2006). Both SMX and EE2 possess these structural characteristics, and past studies have shown that 
they react quickly with $\mathrm{O}_{3}$ with measured rate constants in the range of $10^{5} \mathrm{M}^{-1} \mathrm{~s}^{-1}$ to $10^{9} \mathrm{M}^{-1} \mathrm{~s}^{-1}$ (Deborde et al. 2005; Huber et al. 2003; von Gunten 2003). Pilot and full-scale tests investigating the use of $\mathrm{O}_{3}$ (as an advanced or tertiary treatment step) following AS during WW treatment have found that compounds with reaction rates $>10^{4} \mathrm{M}^{-1} \mathrm{~s}^{-1}$ can be eliminated by up to $95 \%$ prior to final effluent discharge (Huber et al. 2005; Wert et al. 2009). While ozonation generally results in "less-active" by-products (Ternes et al. 2003), it has been shown that the reaction of SMX with $\mathrm{O}_{3}$ can result in the formation of another antibiotic (sulfanilamide) (Yargeau et al. 2008), and the ozonation of EE2, which reduces estrogenicity, has been recently shown to increase toxicity with respect to testosterone secretion by fetal rats (Larcher et al. 2012). Also, it has been shown, using indicators such as biological oxygen demand (BOD) and chemical oxygen demand (COD), that treatment with highly concentrated ozone increases the biodegradability of WW (Beltrán et al. 1999; Ternes et al. 2006) as well as specific compounds such as penicillin, enrofloxacin, ceftriaxone, and bezafibrate (Alaton et al. 2004; Balcioglu and Otker 2003; Dantas et al. 2007, 2008). This has led to the hypothesis that the application of small $\mathrm{O}_{3}$ doses prior to biological WW treatment may be implemented to lower estrogenic and antibacterial activity before exposure to AS microbial populations and increase biodegradation and removal of pharmaceutical compounds and/or potentially harmful ozonation by-products formed (Alvares et al. 2001; Dodd et al. 2009; Zhang et al. 2008).

The aim of this study was to investigate the effect of a low dose of $\mathrm{O}_{3}$ applied prior to biological treatment on the biodegradation of SMX and EE2 at lab-scale using controlled mixtures of pure bacterial cultures that have been previously detected in AS and pharmaceutical WW effluent (Rani et al. 2008; Seviour et al. 2008). Although these pure bacterial mixtures are not representative of the whole range of microorganisms present in actual WW treatment systems, this experimental approach is more realistic than using single-strain pure culture studies and was required in order to maintain a controlled and reproducible system that cannot be obtained using inoculum from AS treatment. This approach allows the study of multiple strains at the same time while maintaining the possibility of comparing results obtained under different experimental conditions.

\section{Materials and methods}

\section{Chemical reactants and reagents}

All chemicals used were of reagent or HPLC grade. EE2 (CAS 57-63-6, purity $98 \%$ ), SMX (CAS 723-46-46), ammonium nitrate $\left(\mathrm{NH}_{4} \mathrm{NO}_{3}\right)$, calcium chloride dihydrate $\left(\mathrm{CaCl}_{2} \cdot 2 \mathrm{H}_{2} \mathrm{O}\right)$, magnesium sulfate heptahydrate $\left(\mathrm{MgSO}_{4} \cdot 7 \mathrm{H}_{2} \mathrm{O}\right)$, ammonium acetate, formic acid, and glucose assay kit (GAHK-20) were purchased from Sigma-Aldrich, Canada. Iron sulfate heptahydrate $\left(\mathrm{FeSO}_{4} \cdot 7 \mathrm{H}_{2} \mathrm{O}\right)$, ethylene diamine tetra-acetic acid (EDTA), sodium hydrogen monophosphate $\left(\mathrm{Na}_{2} \mathrm{HPO}_{4}\right)$, sodium dihydrogen phoshate $\left(\mathrm{NaH}_{2} \mathrm{PO}_{4}\right)$, yeast extract, and acetonitrile (ACN) were purchased from Fisher Scientific, Canada. Anhydrous ethanol (EtOH) was purchased from Commercial Alcohols, Canada. McFarland Standard \#2 was obtained from bioMérieux, France; BHI (Brain Heart Infusion) Agar was obtained from Becton-Dickinson \& Co., Canada; and glucose was obtained from A \& C American Chemicals Ltd., Canada.

Stock solutions of SMX and EE2 were prepared in reverse osmosis (RO) water at the following concentrations: $60 \mathrm{mg} / \mathrm{L} \mathrm{SMX} \mathrm{(6 \%} \mathrm{EtOH)} \mathrm{and} 50 \mathrm{mg} / \mathrm{L} \mathrm{EE2} \mathrm{(5 \%} \mathrm{EtOH),}$ respectively. A stock solution of SMX $(60 \mathrm{mg} / \mathrm{L})$ without EtOH was also prepared in order to determine the effect of EtOH on biodegradation. Stock ozone solutions were prepared as described in "Batch ozonation".

\section{Batch ozonation}

Stock $\mathrm{O}_{3}$ solutions were made by sparging $\mathrm{O}_{3}$ gas produced by an Ozomax generator and a pure oxygen gas feed through a $500-\mathrm{mL}$ gas washing bottle filled with RO water and surrounded by ice. The dissolved $\mathrm{O}_{3}$ was determined spectrophotometrically by measuring the absorbance at $258 \mathrm{~nm}\left(\varepsilon=2,950 \mathrm{M}^{-1} \mathrm{~cm}^{-1}\right)$ (Bader and Hoigné 1981). Due to the nature of batch ozonation and the desired concentrations for the ozonated stock SMX and EE2 solutions, it was necessary to use aliquots of highly concentrated SMX or EE2 solutions made in ethanol $(1,000 \mathrm{mg} / \mathrm{L})$. The volume of $\mathrm{O}_{3}$ stock solution required to achieve a $5 \mathrm{mg} / \mathrm{L} \mathrm{O}_{3}$ dose was added to the experimental SMX $(60 \mathrm{mg} / \mathrm{L})$ or EE2 $(50 \mathrm{mg} / \mathrm{L})$ stock solutions (containing $6 \%$ and $5 \% \mathrm{EtOH}$, respectively) and mixed vigorously until all the $\mathrm{O}_{3}$ had reacted with SMX or EE2 and had dissipated from the solution (approximately $2 \mathrm{~h}$ ). These ozonated SMX and EE2 solutions were then stored at $4{ }^{\circ} \mathrm{C}$ until needed for the biodegradation experiments. Based on the results of a previous study (Rodayan et al. 2010), it was assumed that the reaction pathways between $\mathrm{O}_{3}$ and SMX or EE2 at these higher concentrations were identical to those that would take place at lower concentrations such as those encountered in municipal WW. The addition of small aliquots $(10 \%$ of the total working volume) of these concentrated ozonated stock SMX or EE2 solutions to the experimental flasks resulted in the desired conditions of $6 \mathrm{mg} / \mathrm{L} \mathrm{SMX} \mathrm{or} 5 \mathrm{mg} / \mathrm{L}$ EE2 treated with $0.5 \mathrm{mg} / \mathrm{L} \mathrm{O}_{3}$. This ten-time dilution of the ozonated stock solutions ensured that SMX, EE2, and EtOH $(0.6 \%$ and $0.5 \% \mathrm{v} / \mathrm{v})$ were at levels that were not observed to be growth-limiting. It should also be noted that the reaction rate of $\mathrm{EtOH}$ with $\mathrm{O}_{3}$ ranges from 0.45 to 
$0.77 \mathrm{M}^{-1} \mathrm{~s}^{-1}$ (Yao and Haag 1991), which is much lower than that of SMX $\left(2.5 \times 10^{6} \mathrm{M}^{-1} \mathrm{~s}^{-1}\right)$ (Huber et al. 2003) or EE2 $\left(1.83 \times 10^{5}\right.$ to $\left.3.65 \times 10^{9} \mathrm{M}^{-1} \mathrm{~s}^{-1}\right)$ (Deborde et al. 2005). It is thus expected that EtOH would not impede the reaction of either compound with $\mathrm{O}_{3}$. This hypothesis was confirmed by gas chromatography analysis indicating no changes in the concentration of EtOH after ozonation.

\section{Biological and chemical oxygen demand (BOD/COD)}

The 5-day biological oxygen demand $\left(\mathrm{BOD}_{5}\right)$ was measured according to Standard Method 5210D (Standard Methods for the Examination of Water and Wastewater) using Polyseed $^{\mathrm{TM}}$ BOD seed inoculum. The dissolved oxygen was measured using a BOD self-stirring probe (Thermo Scientific, 13-620-SSP) and an Accumet Excel XL60 Dual Channel pH/Ion/Conductivity/DO meter (Fisher Scientific). COD was measured according to Standard Method 5220D using a HACH Digital Reactor Block 200 (DRB 200) and a HACH spectrophotometer $\mathrm{DR} / 2500$. The $\mathrm{BOD}_{5}: \mathrm{COD}$ ratio was used as a tool to evaluate biodegradability.

\section{Individual bacteria}

The pure bacterial cultures used in this study were obtained from Cedarlane ${ }^{\circledR}$ Canada and stored at $-80{ }^{\circ} \mathrm{C}$ in a BHI/ glycerol mixture. Each bacteria was thawed and grown individually in BHI broth for $24 \mathrm{~h}$ at $26^{\circ} \mathrm{C}$ and $150 \mathrm{rpm}$ (INNOVA ${ }^{\circledR} 44$ Incubator Shaker Series) and then plated and grown on BHI agar. After incubation for 24 to $48 \mathrm{~h}$ at $26^{\circ} \mathrm{C}$ in the dark, the agar plates were stored at $4{ }^{\circ} \mathrm{C}$. The seven bacteria used in this study were (ATCC\#): Bacillus subtilis (6051), Pseudomonas aeruginosa (PA01), Pseudomonas putida (12633), Rhodococcus equi (13557), Rhodococcus erythropolis (4277), Rhodococcus rhodochrous (13808), and Rhodococcus zopfii (51349). These bacteria were chosen due to their previous detection and isolation from WWTP-AS and for their facility treating pharmaceutical effluent and/or their demonstrated ability to degrade EE2 or SMX (Gauthier et al. 2010; O'Grady et al. 2009; Rani et al. 2008; Seviour et al. 2008; Yoshimoto et al. 2004).

\section{Mixed bacterial groups and inhibition}

Prior to mixing the bacteria together, inhibition tests were conducted as described elsewhere (Larcher and Yargeau 2011) in order to determine the final bacterial mixtures used in this study. Based on the results, two different bacterial mixtures were studied in order to consider all the strains while avoiding inhibition problems. Group 1 consisted of $P$. aeruginosa, $P$. putida, $R$. equi, $R$. erythropolis, and $R$. rhodochrous; and Group 2 consisted of B. subtilis, P. putida, $R$. equi, $R$. erythropolis, $R$. rhodochrous, and $R$. zopfii.
Biodegradation

Experiments were carried out in duplicate using the bacterial mixtures in Group 1 and Group 2 and SMX or EE2 solutions with and without pre-treatment with $\mathrm{O}_{3}$, and with or without an additional source of easily degraded carbon (glucose). For each bacteria, the growth on BHI agar plates was used to make cellular standards (McFarland Standard $\# 2 ; 3 \times 10^{8}$ cells $/ \mathrm{mL}$ ) in $6 \mathrm{~mL}$ of a $0.85 \%$ sterile sodium chloride solution. These were used to pre-inoculate $250-\mathrm{mL}$ Erlenmeyer flasks (working volume of $100 \mathrm{~mL}$ ) containing minimum mineral salt media (MMSM), $6 \mathrm{mg} / \mathrm{L} \mathrm{SMX,} \mathrm{or}$ $5 \mathrm{mg} / \mathrm{L}$ EE2 (from the addition of a small aliquot of $60 \mathrm{mg} / \mathrm{L}$ $\mathrm{SMX}$ or $50 \mathrm{mg} / \mathrm{L}$ EE2 stock solutions with and without prior $\mathrm{O}_{3}$ treatment) and were placed in a dark incubator shaker $\left(24 \mathrm{~h}, 26^{\circ} \mathrm{C}, 150 \mathrm{rpm}\right)$. This pre-inoculant was prepared in order to acclimate each of the seven bacteria to the test conditions. The MMSM used was composed of $\mathrm{Na}_{2} \mathrm{ED}$ $\mathrm{TA} \cdot 2 \mathrm{H}_{2} \mathrm{O}(0.018 \mathrm{~g} / \mathrm{L}), \mathrm{FeSO}_{4} \cdot 7 \mathrm{H}_{2} \mathrm{O}(0.013 \mathrm{~g} / \mathrm{L})$, $\mathrm{CaCl}_{2} \cdot 2 \mathrm{H}_{2} \mathrm{O}(0.013 \mathrm{~g} / \mathrm{L}), \mathrm{MgSO}_{4} \cdot 7 \mathrm{H}_{2} \mathrm{O}(0.25 \mathrm{~g} / \mathrm{L})$, $\mathrm{Na}_{2} \mathrm{HPO}_{4}(7.5 \mathrm{~g} / \mathrm{L}), \mathrm{KH}_{2} \mathrm{PO}_{4}(5 \mathrm{~g} / \mathrm{L})$, and $\mathrm{NH}_{4} \mathrm{NO}_{3}(5 \mathrm{~g} /$ $\mathrm{L})$. Yeast extract was also added to the aqueous matrix at $0.6 \mathrm{~g} / \mathrm{L}$ of the working volume (Gauthier et al. 2010). Equal volumes of each pre-inoculant individual bacterial growth were used to inoculate the $500-\mathrm{mL}$ experimental Erlenmeyer flasks (working volume of $350 \mathrm{~mL}$ ). The total volume of the mixed bacterial pre-inoculants added to each experimental flask was $70 \mathrm{~mL}$ ( $20 \%$ of the total working volume). The experimental flasks contained the same aqueous matrix as the pre-inoculant flasks. It should be noted that the aliquots of SMX or EE2 stock solutions added to each experimental flask were based on achieving initial concentrations of $6 \mathrm{mg} /$ L SMX or $5 \mathrm{mg} / \mathrm{L}$ EE2 in a total working volume of $350 \mathrm{~mL}$ assuming that no residual SMX or EE2 remained in the transferred inoculum from the pre-inoculant flasks. However, SMX and EE2 were consistently transferred from the preinoculant to the experimental flasks, explaining the observed initial concentrations that were slightly higher than $6 \mathrm{mg} / \mathrm{L} \mathrm{SMX}$ or $5 \mathrm{mg} / \mathrm{L} \mathrm{EE} 2$. For ease of analysis, the SMX and EE2 concentrations used in this study are higher than those encountered in WW, which has also occurred in previous studies where SMX concentrations ranged from $3.76 \mathrm{mg} / \mathrm{L}$ to $100 \mathrm{mg} / \mathrm{L}$ (Alexy et al. 2004; Drillia et al. 2005; Gauthier et al. 2010) and EE2 concentrations ranged from 3.5 to $100 \mathrm{mg} / \mathrm{L}$ (Weber et al. 2005; Yoshimoto et al. 2004).

Control experiments were carried out with each mixed bacteria group to verify that any metabolites detected were due solely to SMX or EE2 transformation by conducting the above described biodegradation experiments with no SMX or EE2. Adsorption onto the bacteria was also found to be within the error of analysis ( $\pm 2 \%)$ as indicated by experiments conducted with bacteria killed via autoclaving 
immediately after pre-inoculation. Growth tests were carried out on BHI agar plates at the SMX, EE2, and EtOH concentrations used in this study; no inhibitory effect on the growth of the seven bacteria was observed.

\section{Analytical methods}

Bacterial growth was measured via the optical density at $540 \mathrm{~nm}\left(\mathrm{O}^{\mathrm{D}} \mathrm{D}_{540}\right)$ using a Thermo Evolution $300 \mathrm{UV}-$ Visible Spectrophotometer. To monitor the concentration of SMX or EE2, $2 \mathrm{~mL}$ aliquots were removed from each experimental flask over time and centrifuged at 10,000 rpm for $10 \mathrm{~min}$ (Thermo IEC MicroCL 21). The supernatant was syringefiltered with a $0.22-\mu \mathrm{m}$ PVDF filter directly into an amber vial for HPLC analysis.

Determination of SMX was carried out using an Agilent 1200 HPLC equipped with a Diode Array Detector (DAD) at a wavelength of $273 \mathrm{~nm}$ and a XDB Phenyl column $(150 \times 4.6 \mathrm{~mm}, 3.5 \mu \mathrm{m})$. Mobile phases consisted of $20 \mathrm{mM} \mathrm{NaH} \mathrm{PO}_{4}$ (pH 2.8 using phosphoric acid) and $\mathrm{ACN}$ using a gradient from $30 \%$ to $45 \% \mathrm{ACN}$ over $10 \mathrm{~min}$; the method used a column temperature of $40{ }^{\circ} \mathrm{C}$, an injection volume of $10 \mu \mathrm{L}$, and a flow rate of $0.7 \mathrm{~mL} /$ min. The limit of detection and limit of quantitation were $2 \mu \mathrm{g} / \mathrm{L}$ and $7 \mu \mathrm{g} / \mathrm{L}$, respectively.

Determination of EE2 was carried out using the same HPLC and detector at a wavelength of $279 \mathrm{~nm}$ and a Zorbax Eclipse Plus C18 column $(150 \times 4.6 \mathrm{~mm}, 3.5 \mu \mathrm{m})$. Mobile phases consisted of $0.5 \mathrm{mM}$ ammonium acetate $(\mathrm{pH} 2.8$ using formic acid) and ACN using a gradient from $30 \%$ to $60 \% \mathrm{ACN}$ over $20 \mathrm{~min}$; the method used a column temperature of $28{ }^{\circ} \mathrm{C}$, an injection volume of $50 \mu \mathrm{L}$, and a flow rate of $0.8 \mathrm{~mL} / \mathrm{min}$. The limit of detection and limit of quantitation were $125 \mu \mathrm{g} / \mathrm{L}$ and $417 \mu \mathrm{g} / \mathrm{L}$, respectively.

Determination of ethanol in the EE2 and SMX stock solutions before and after ozonation was carried out using an HP 5890 Gas Chromatograph equipped with a flame ionization detector (FID) and a Restek Stabilwax ${ }^{\circledR}$ column $(30 \mathrm{~m} \times 0.32 \mathrm{~mm}, 0.25 \mu \mathrm{m})$. The carrier gas was helium at a constant flow of $30 \mathrm{~mL} / \mathrm{min}$, with an injection volume of $2 \mu \mathrm{L}$ (direct injection). The detector and injector temperature was $175^{\circ} \mathrm{C}$ with an oven temperature of $130{ }^{\circ} \mathrm{C}$.

\section{Results}

\section{Effect of EtOH on SMX biodegradation}

Due to the low solubility of EE2 in pure RO water, it was not possible to carry out experiments without diluting a concentrated stock solution made in EtOH. However, it was possible to make two different $60 \mathrm{mg} / \mathrm{L}$ SMX solutions - one in pure RO water and another made by diluting a
$1,000 \mathrm{mg} / \mathrm{L}$ SMX solution (made in $100 \% \mathrm{EtOH}$ )—which were each used in separate biodegradation experiments to compare the effect of EtOH on bacterial growth and SMX removal. Aliquots of the SMX stock solution were added to each pre-inoculant and experimental flask in order to achieve $6 \mathrm{mg} / \mathrm{L}$ SMX and $0.6 \%(\mathrm{v} / \mathrm{v}) \mathrm{EtOH}$ for the flask prepared using the stock solution containing the solvent. This amount of EtOH was not inhibitory; however, its presence had a significant effect on both the bacterial growth and SMX removal. Without EtOH the maximum SMX removal achieved by either mixed group of bacteria after $300 \mathrm{~h}$ was $5 \%$; however, with EtOH, Group 1 achieved approximately $40 \%$ SMX removal and Group 2 achieved $15 \%$ SMX removal. There was also a metabolite peak eluted 0.3 min before SMX during HPLC analysis in both groups grown in the presence of $\mathrm{EtOH}$, which was four times larger in Group 1. Without EtOH, both Group 1 and Group 2 grew to a maximum O.D $D_{540}$ of 0.6 , while the maximum O.D $D_{540}$ achieved in the presence of EtOH by both groups was approximately 2.5 . These results clearly show that the presence of EtOH enhanced the growth of both mixed bacterial groups (more than four times) and increased SMX removal by a factor of 3 (Group 2) to 8 (Group 1).

\section{Effect of $\mathrm{O}_{3}$ on the $\mathrm{BOD}_{5}$ :COD}

The change in biodegradability of a $6 \mathrm{mg} / \mathrm{L}$ SMX solution in pure RO water (with no additional carbon sources, i.e., no $\mathrm{EtOH})$ due to the application of $0.5 \mathrm{mg} / \mathrm{L} \mathrm{O}_{3}$ was estimated using the measured $\mathrm{BOD}_{5}$ :COD. This analysis was carried out in triplicate with results showing that the $\mathrm{BOD}_{5}: \mathrm{COD}$ increased from $0.2 \pm 0.1$ without $\mathrm{O}_{3}$ to $5.1 \pm 0.4$ after $\mathrm{O}_{3}$ treatment. The $\mathrm{BOD}_{5}$ :COD was not measured for EE2 because it was necessary to dilute a concentrated EE2 solution made in EtOH to achieve the desired $5 \mathrm{mg} / \mathrm{L}$ concentration. This would result in the presence of $0.5 \%(\mathrm{v} / \mathrm{v}) \mathrm{EtOH}$, which would render the $\mathrm{BOD}_{5}$ and $\mathrm{COD}$ analyses ineffective.

\section{Effect of $\mathrm{O}_{3}$ on SMX biodegradation}

Without $\mathrm{O}_{3}$ pre-treatment, the growth of each mixed bacterial group was virtually identical, attaining a maximum O.D S40 $_{540}$ of approximately 2.5 (Group 2) to 2.7 (Group 1). However, these similar growth patterns did not result in the same observed SMX removals (Fig. 1a and b). Group 1 achieved approximately $42 \%$ SMX removal after $300 \mathrm{~h}$, and a metabolite peak was detected during HPLC analysis, which eluted 0.3 min earlier than SMX (Fig. 1a). Group 2 achieved less SMX removal after $300 \mathrm{~h}(15 \%)$ with a metabolite peak detected at the same time as Group 1, but approximately five times smaller (Fig. 1b). 
The results show that after ozonation (where $10 \%$ of the initial SMX disappeared due to reaction with $\mathrm{O}_{3}$ ), the growth of each bacterial mixture was relatively unchanged, with maximum O.D $D_{540}$ values ranging from 2.4 to 2.7. The SMX removed via biodegradation after $300 \mathrm{~h}$ by Group 1 was increased from $42 \%$ to $47 \%$ after ozonation (Fig. 1a). When combined with the $10 \%$ SMX removal due to reaction with ozone, the overall SMX removal achieved by Group 1 was $57 \%, 15 \%$ greater than without $\mathrm{O}_{3}$ pre-treatment. The results of Group 2 were more impressive with the SMX removal increasing from $15 \%$ to $55 \%$ after ozonation (Fig. 1b). When added to the removal resulting from reaction with $\mathrm{O}_{3}$, the overall SMX removal achieved by Group 2 was $65 \%$. For both Group 1 and Group 2, the same metabolite peak was detected as without $\mathrm{O}_{3}$ pre-treatment.

\section{Effect of $\mathrm{O}_{3}$ on EE2 biodegradation}

Without $\mathrm{O}_{3}$ pretreatment, the growth of the bacteria reached maximum O.D $\mathrm{D}_{540}$ values of 2.2 (Group 2) to 2.7 (Group 1), and each bacterial mixture removed the same amount of EE2 after $300 \mathrm{~h}(42-43 \%)$.

After ozonation, $45 \%$ of the initial EE2 disappeared and an $\mathrm{EE} 2+\mathrm{O}_{3}$ by-product peak was consistently detected at the wavelength of HPLC analysis. The growth of the bacteria was relatively unchanged after ozone treatment with maximum O.D ${ }_{540}$ values of 2.6 (Group 1) and 2.2 (Group 2). The EE2 removal achieved by both mixed bacterial groups did not increase after $\mathrm{O}_{3}$ treatment; Group 1 achieved $20 \%$ EE2 removal after $300 \mathrm{~h}$ (compared to $43 \%$ without $\mathrm{O}_{3}$ ) (Fig. 2a), while Group 2 removed $40 \%$ EE2 (compared to $42 \%$ without $\mathrm{O}_{3}$ ) (Fig. 2b). However, the overall EE2 removals achieved were greater than those without $\mathrm{O}_{3}$ pretreatment, since almost half of the initial EE2 disappeared after reaction with $\mathrm{O}_{3}$.

Effect of an additional carbon source on SMX and EE2 biodegradation

Experiments were carried out with an additional readily degradable carbon source $(0.5 \mathrm{~g} / \mathrm{L}$ glucose $)$ to investigate the effect on bacterial growth and removal of SMX and EE2 (both with and without ozone pre-treatment). For all of the conditions investigated, the addition of glucose did not greatly increase the bacterial cell density (not shown) which indicates that it did not promote a detectable increase in bacterial growth. Despite this similar bacterial growth of the mixed bacteria, there were some differences observed in the SMX and EE2 removals (Table 1). Without ozone pretreatment, Group 1 had similar SMX removal regardless of glucose (40-42\%) but drastically less EE2 removal with glucose addition ( $25 \%$ vs. $43 \%$ without glucose). The EE2 removed by Group 2 was not affected by glucose addition
(42-43\% removal) but there was two times more SMX removed with glucose present (31\% vs. $15 \%$ without glucose).

After ozonation of the SMX and EE2 solutions, the observed effect of glucose addition was different (Table 1). While Group 1 achieved similar removals of EE2 (20-17\%) and only slightly higher SMX removal with glucose (59\% vs. $47 \%$ without glucose), Group 2 removed significantly less EE2 and SMX in the presence of glucose (20\% each vs. $40 \%$ EE2 removal and $55 \%$ SMX removal without glucose).

Glucose concentrations were measured at three different times throughout the experiments $(0,120$, and $300 \mathrm{~h})$ and the results (not shown) illustrate that the overall glucose consumption by Groups 1 and 2 was identical regardless of ozonation for both SMX (98 $\pm 0.4 \%$ glucose consumption) and EE2 ( $98.5 \pm 0.3 \%$ glucose consumption).

\section{Discussion}

\section{SMX degradation}

The presence of $0.5 \%(\mathrm{v} / \mathrm{v})$ EtOH was observed to result in enhanced bacterial growth and increased SMX removal; this is not unexpected since a previous study observed the same trends due to the presence of methanol (Radke et al. 2009). Therefore, it should be kept in mind that the observed removals of SMX during the biodegradation experiments in this study may be elevated due to the presence of EtOH. This is not an unrealistic set of conditions as this phenomenon might be observed in treatment plants treating WW containing a variety of additional sources of carbon.

The measured SMX percent removals (15\% to $42 \%$ ) are lower than previously published results of lab-scale experiments conducted with various AS samples (Drillia et al. 2005; Perez et al. 2005) where up to complete SMX removal was observed. However, they are closer to the SMX removal predicted by the biological degradation constant $\left(k_{\text {biol }}\right)$ determined at batch-scale using AS samples $\left(0.1<k_{\text {biol }}<1\right.$ $\mathrm{Lg}_{\mathrm{ss}}{ }^{-1} \mathrm{day}^{-1}$ ), which suggested approximately $20 \%$ removal would occur via biodegradation (Joss et al. 2006). The difference between the SMX degradation achieved by the two mixed groups may be a result of the different microbial populations, specifically the presence (Group 1) or absence (Group 2) of $P$. aeruginosa which is known to produce the enzyme arylamine $\mathrm{N}$-acetyltransferase (BRENDA: The Comprehensive Enzyme Information System). Based on the specificity of this enzyme to attack SMX, the mixture containing $P$. aeruginosa (Group 1) would be expected to be more successful at degrading SMX than the one without $P$. aeruginosa (Group 2), which was observed in this study.

Prior to carrying out biodegradation experiments to investigate the impact of ozone pre-treatment, an initial 

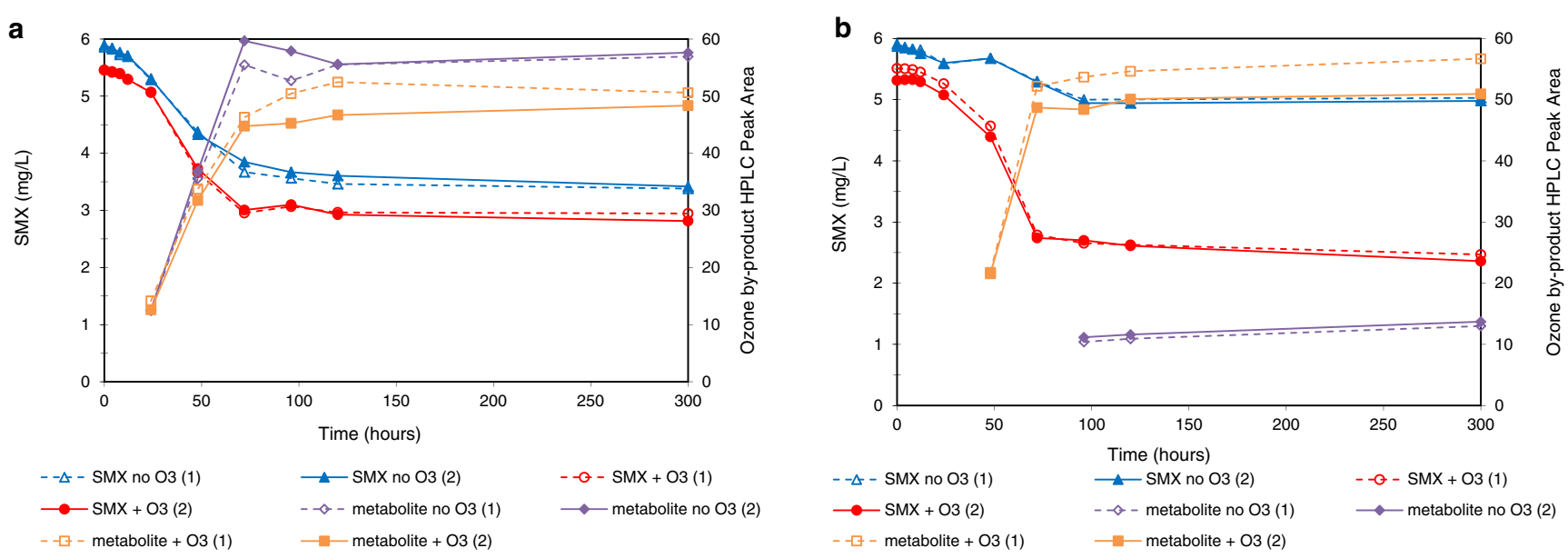

Fig. 1 Sulfamethoxazole (SMX) removal by mixed bacterial cultures with and without ozone $\left(\mathrm{O}_{3}\right)$ pre-treatment. a Group 1 ( $P$. aeruginosa, $P$. putida, R. equi, R. erythropolis, and R. rhodochrous); b Group 2 (B. subtilis, P. putida, R. equi, R. erythropolis, $R$. rhodochrous, and $R$. zopfii)

analysis was performed using the measured $\mathrm{BOD}_{5}: \mathrm{COD}$ of a $6 \mathrm{mg} / \mathrm{L}$ SMX solution with and without ozone treatment. In past studies, this ratio has been shown to increase after ozonation of WWs (Beltrán et al. 1999) and SMX solutions (Dantas et al. 2008), which predicts increased biodegradability. In this study, the average $\mathrm{BOD}_{5}$ : $\mathrm{COD}$ (performed in triplicate) of the SMX solutions increased by a factor of 25 after reaction with $\mathrm{O}_{3}$, which indicates that the biodegradability of the solution was greatly increased.

It was expected, due to the increased $\mathrm{BOD}_{5}$ :COD measured after $\mathrm{O}_{3}$ application, that ozonation would result in the observed increase in biodegradation of SMX. This increased biological removal of SMX observed after ozonation may have been due to the formation of $\mathrm{SMX}+\mathrm{O}_{3}$ by-products (undetected by the analytical method used) that encouraged cometabolism of SMX. Several potential ozone by-products have been detected (Dantas et al. 2008) and identified (Rodayan et al. 2010) under different conditions in other studies, and it is possible that some of these previously identified by-products of SMX ozonation were formed in this study. It has also been shown that ozonation of SMX results in decreased antibacterial activity (Dodd et al. 2009) and the formation of bioactive by-products that do not negatively affect the proliferation of mammalian cells and may even stimulate cell growth (Yargeau et al. 2008). These post-ozonization properties may have added to the observed increase in SMX removal by the bacterial mixtures after reaction with $\mathrm{O}_{3}$.

The potential structures of the compounds contained in the detected metabolite peak formed during the biodegradation of SMX by Groups 1 and 2 were proposed in a previous study based on the enzymes produced by Rhodococcus species in general and $R$. equi specifically (Larcher and Yargeau 2011). The enzyme arylamine N-acetyltransferase is produced by Rhodococcus species; this enzyme specifically attacks compounds containing aromatic amine structures and is known to use SMX as a substrate (BRENDA: The Comprehensive Enzyme Information System). Since both mixed groups contain three to four different types of
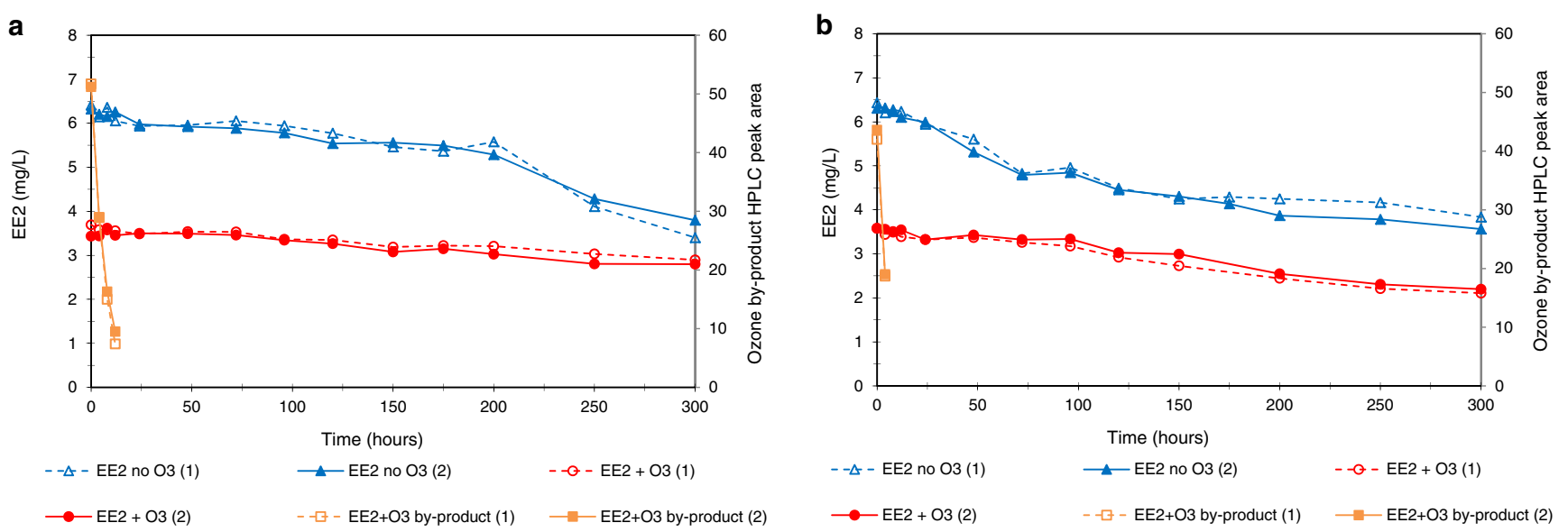

Fig. $217 \alpha$-ethinylestradiol (EE2) removal by mixed bacterial cultures with and without ozone $\left(\mathrm{O}_{3}\right)$ pre-treatment. a Group 1 (P. aeruginosa, $P$. putida, R. equi, R. erythropolis, and R. rhodochrous); b Group 2 (B. subtilis, P. putida, R. equi, R. erythropolis, R. rhodochrous, and R. zopfii) 
Table 1 Summary of percent removals of EE2 and SMX after $300 \mathrm{~h}$ by mixed bacterial cultures in Group 1 ( $P$. aeruginosa, $P$. putida, $R$. equi, R. erythropolis, and R. rhodochrous) and Group 2 (B. subtilis, $P$. putida, $R$. equi, $R$. erythropolis, $R$. rhodochrous, and $R$. zopfii) with and without ozone $\left(\mathrm{O}_{3}\right)$ pre-treatment and an additional source of readily degradable carbon $(0.5 \mathrm{~g} / \mathrm{L}$ glucose $)$

\begin{tabular}{|c|c|c|c|c|}
\hline \multirow[t]{3}{*}{ Mixed bacteria } & \multicolumn{4}{|c|}{ Percent removal after $300 \mathrm{~h}^{\mathrm{a}}$} \\
\hline & \multicolumn{2}{|l|}{ EE2 } & \multicolumn{2}{|l|}{ SMX } \\
\hline & No glucose & With glucose & No glucose & With glucose \\
\hline Group 1 & $43 \% \pm 3.5 \%$ & $25 \% \pm 1.7 \%$ & $42 \% \pm 0.3 \%$ & $40 \% \pm 3 \%$ \\
\hline Group 2 & $42 \% \pm 1.5 \%$ & $43 \% \pm 1.7 \%$ & $15 \% \pm 0.2 \%$ & $31 \% \pm 0.4 \%$ \\
\hline Group 1 (pre- $\left.\mathrm{O}_{3}\right)$ & $20 \% \pm 1.5 \%$ & $17 \% \pm 0.8 \%$ & $47 \% \pm 1.2 \%$ & $59 \% \pm 0.1 \%$ \\
\hline Group 2(pre- $\left.\mathrm{O}_{3}\right)$ & $40 \% \pm 1.5 \%$ & $20 \% \pm 1.2 \%$ & $55 \% \pm 0.2 \%$ & $20 \% \pm 1.5 \%$ \\
\hline
\end{tabular}

${ }^{\text {a }}$ Average of duplicate experiments \pm range in values

Rhodococcus bacteria, it is hypothesized that the production of this enzyme would result in a metabolite with an acetyl group attached to the aromatic amine in SMX as was proposed previously. This same study also suggested that $R$. equi is capable of producing several different enzymes that might lead to the hydrolysis of the proposed acetylated metabolite to potentially form an alcohol derivative. Both of these potential metabolite structures are more polar than SMX, which would result in their observed earlier elution during the HPLC analysis used.

\section{EE2 degradation}

The approximately $40 \%$ EE2 removal via biodegradation that was observed in this study using the two defined bacterial mixtures (Groups 1 and 2) is not completely surprising as a previous lab-scale investigation using AS samples predicted that EE2 would be partially removed during biodegradation (Joss et al. 2006). However, despite this prediction of partial biodegradation, there have been variable results reported from batch experiments using AS ranging from 0 (Weber et al. 2005) to $100 \%$ (Hashimoto and Murakami 2009) EE2 removal. There are also conflicting results from past studies investigating the role played by the type of AS on EE2 degradation. While some studies have shown nitrifying AS to degrade EE2 more successfully than the heterotrophic bacteria in conventional AS (Ren et al. 2007; Vader et al. 2000), others have shown heterotrophs to be more effective at degrading EE2 (Gaulke et al. 2008) and its metabolites (Shi et al. 2004). Thus, past results are highly variable (due to differences in experimental protocols and bacterial population in AS samples), but this study demonstrates that EE2 is partially biodegraded by the controlled mixtures of heterotrophic bacteria in Group 1 and Group 2. This may be due to the presence of up to four Rhodococcus species in each mixture, since this genus is capable of degrading organic compounds that are structurally similar to EE2 (Larkin et al. 2005; Martínková et al. 2009). Also, R. equi and $R$. zopfii have specifically demonstrated EE2-degrading capabilities in past studies (Yoshimoto et al. 2004; O'Grady et al. 2009).

The decreased biodegradation of EE2 after ozonation may be due to the formation of the EE2 ozonation transformation product that was detected as a peak that was eluted 5 min prior to EE2 during HPLC analysis. Figure $2 \mathrm{a}$ and $\mathrm{b}$ show that this transformation product was degraded quickly by both bacterial groups suggesting that it was preferentially degraded by the bacteria over EE2. HPLC analysis conducted at a different wavelength of detection $(250 \mathrm{~nm})$ showed that another EE2 ozonation transformation product was formed $\left(\mathrm{O}_{3}\right.$ by-product $\left.\mathrm{B}\right)$ which grew in size as the other one was rapidly degraded $\left(\mathrm{O}_{3}\right.$ by-product $\left.\mathrm{A}\right)$. Another metabolite having a different HPLC retention time that formed after $24 \mathrm{~h}$ in Group 1 was also detected. The transformation product $\left(\mathrm{O}_{3}\right.$ by-product $\left.\mathrm{B}\right)$ and metabolite detected at a wavelength of $250 \mathrm{~nm}$ persisted throughout the biodegradation experiment but appears to have been slightly degraded (Fig. 3a and b). The formation of a persistent metabolite in Group 1 only may be the cause of the significantly reduced EE2 removal after $\mathrm{O}_{3}$ treatment in this bacterial mixture compared to Group 2. Thus, the decreased EE2 biodegradation observed after ozone treatment may have been due to the preferential quick degradation of the first transformation product $\left(\mathrm{O}_{3}\right.$ by-product $\left.\mathrm{A}\right)$ combined with the slow degradation of the other transformation product $\left(\mathrm{O}_{3}\right.$ by-product $\left.\mathrm{B}\right)$ and metabolite. The HPLC retention time of these two transformation products corresponds to those observed in a previous study using the same analytical method in which the degradation of EE2 due to ozonation and the resulting impacts on estrogenicity and toxicity were investigated (Larcher et al. 2012). Results showed that these peaks were comprised of several compounds of which only two were successfully identified. These transformation products were both muconic acid derivatives with open phenolic ring structures and molecular weights of 302 and $344 \mathrm{gmol}^{-1}$. The results of another study modeling the effect 
Fig. 3 Formation and removal of ozone by-products of $17 \alpha$-ethinylestradiol (EE2) and a metabolite by mixed bacterial cultures: a Group $1(P$. aeruginosa, $P$. putida, $R$. equi, $R$. erythropolis and $R$. rhodochrous) and b Group 2 (B. subtilis, P. putida, R. equi, $R$. erythropolis, $R$. rhodochrous, and $R$. zopfii). HPLC analysis conducted at a detection wavelength of $250 \mathrm{~nm}$
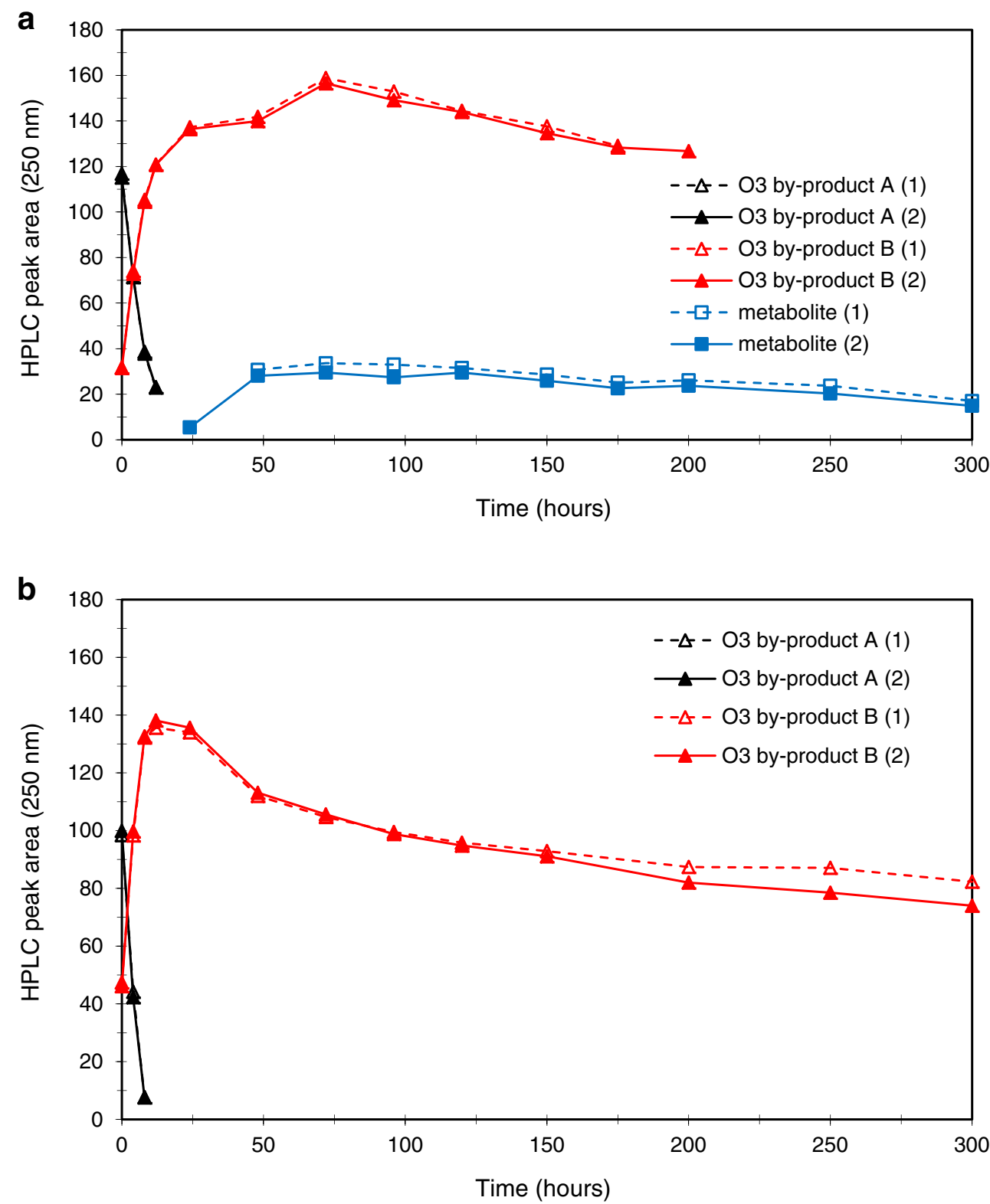

of compound structure on biodegradability showed that closed aromatic rings tended to retard the predicted biodegradation (Loonen et al. 1999); this may be one of the reasons for the observed preferential biodegradation of the transformation products compared to EE2.

Impact of glucose addition

This study demonstrates that the presence of a source of readily degradable carbon (in addition to the pharmaceutical compound being studied and the ethanol and yeast present in the aqueous matrix) does not always result in a predictable trend in the biodegradation of pharmaceutical compounds. In some cases the overall removal may increase, while in others the opposite may occur and there can also be no observed change. The effect of glucose addition seems to depend on the type of compound being degraded and the composition of the mixed bacterial culture, which is known to be highly variable from one AS treatment plant to another.

It is possible that, depending on the bacterial species present in the mixed culture and the pharmaceutical compound being degraded, the addition of a readily degradable carbon source and its subsequent consumption may lead to increased removal of the pharmaceutical compound via cometabolism or decreased removal due to preferential consumption of the readily degradable carbon source or a transformation product. Exploration of these possibilities was not within the scope of this study but should be considered for future work.

Our results agree with the variability observed in previously reported batch studies carried out with AS samples. In these 
studies, SMX removals were both enhanced (Alexy et al. 2004) and inhibited (Drillia et al. 2005) by additional sources of carbon and 20 times less EE2 removal was observed in the presence of excess carbon (Muller et al. 2010). This also illustrates that variation in the microbial population of a mixed consortium of bacteria, whether AS or pure cultures, can cause drastic differences in the biodegradation trends observed. This suggests that the bacterial species making up the mixture being used must be identical in order to compare the results of lab-scale degradation studies.

\section{Overall implications}

This study demonstrates that the application of ozone $\left(\mathrm{O}_{3}\right)$ may result in increased biodegradation of pharmaceutical compounds; however, the results vary depending on the microbial population, the presence of additional carbon sources, and the nature of the pharmaceuticals. The biological removal of the antibiotic SMX generally increased after ozonation, but the mechanisms causing this observation require further study. For the estrogen EE2, where the reaction with $\mathrm{O}_{3}$ results in the formation of a transformation product that was preferentially degraded by the bacteria being studied, $\mathrm{O}_{3}$ pre-treatment resulted in decreased biodegradation of EE2 (the parent compound). It might be possible that a larger $\mathrm{O}_{3}$ dose would result in the complete disappearance of EE2 and the formation of more biodegradable transformation products, which would, in turn, be quickly degraded by the bacteria. These results imply that the use of ozone as a pre-treatment to biological treatment (at doses less than or equal to those used for tertiary treatment following AS) can potentially be considered as an alternative way to implement $\mathrm{O}_{3}$ and achieve added benefits during WW treatment. In addition, the fact that opposing results were obtained for EE2 and SMX indicate that further studies are required to assess the potential of ozonation prior to biological treatment for this important class of contaminants of emerging concern.

Acknowledgments This work was funded by the McGill Engineering Doctoral Award (MEDA), the J.W. McConnell Foundation, the Natural Sciences and Engineering Research Council of Canada (NSERC), and Health Canada.

\section{References}

Alaton IA, Dogruel S, Baykal E, Gerone G (2004) Combined chemical and biological oxidation of penicillin formulation effluent. $\mathrm{J}$ Environ Manage 73(2):155-163

Alexy R, Kumpel T, Kummerer K (2004) Assessment of degradation of 18 antibiotics in the closed bottle test. Chemosphere 57 (6):505-512

Alvares ABC, Diaper C, Parsons SA (2001) Partial oxidation by ozone to remove recalcitrance from wastewaters - a review. Environ Technol 22(4):409-427
Andersson DI (2003) Persistence of antibiotic resistant bacteria. Curr Opin Microbiol 6(5):452-456

Bader H, Hoigné J (1981) Determination of ozone in water by the indigo method. Water Res 15(4):449-456

Balcioglu IA, Otker M (2003) Treatment of pharmaceutical wastewater containing antibiotics by $\mathrm{O} 3$ and $\mathrm{O} 3 / \mathrm{H} 2 \mathrm{O} 2$ processes. Chemosphere 50(1):85-95

Beltrán FJ, García-Araya JF, Álvarez PM (1999) Integration of continuous biological and chemical (ozone) treatment of domestic wastewater: 2. Ozonation followed by biological oxidation. J Chem Technol Biotechnol 74(9):884-890

BRENDA The Comprehensive Enzyme Information System http:// www.brenda-enzymes.org/index.php4. Accessed 27 Feb 2011

Cavallucci S (2007) Top 200: What's topping the charts in prescription drugs this year? Pharmacy practice, Canadian Healthcare Network (http://www.imshealthcanada.com/vgn/images/portal/ cit_40000873/13/31/8286270612-TOP200-07-final.pdf)

Dantas RF, Canterino M, Marotta R, Sans C, Esplugas S, Andreozzi R (2007) Bezafibrate removal by means of ozonation: primary intermediates, kinetics, and toxicity assessment. Water Res 41 (12):2525-2532

Dantas RF, Contreras S, Sans C, Esplugas S (2008) Sulfamethoxazole abatement by means of ozonation. J Hazard Mater 150:790-794

Deborde M, Rabouan S, Duguet JP, Legube B (2005) Kinetics of aqueous ozone-induced oxidation of some endocrine disruptors. Environ Sci Technol 39(16):6086-6092

Dodd MC, Kohler H-PE, von Gunten U (2009) Oxidation of antibacterial compounds by ozone and hydroxyl radical: elimination of biological activity during aqueous ozonation processes. Environ Sci Technol 43(7):2498-2504

Drillia P, Dokianakis SN, Fountoulakis MS, Kornaros M, Stamatelatou $\mathrm{K}$, Lyberatos $\mathrm{G}$ (2005) On the occasional biodegradation of pharmaceuticals in the activated sludge process: the example of the antibiotic sulfamethoxazole. J Hazard Mater 122(3):259-265

Gaulke LS, Strand SE, Kalhorn TF, Stensel HD (2008) $17 \alpha$ Ethinylestradiol transformation via abiotic nitration in the presence of ammonia oxidizing bacteria. Environ Sci Technol 42 (20):7622-7627

Gauthier H, Yargeau V, Cooper DG (2010) Biodegradation of pharmaceuticals by Rhodococcus rhodochrous and Aspergillus niger by cometabolism. Sci Total Environ 408(7):1701-1706. doi:10.1016/ j.scitotenv.2009.12.012

Hashimoto T, Murakami T (2009) Removal and degradation characteristics of natural and synthetic estrogens by activated sludge in batch experiments. Water Res 43(3):573-582

Huber MM, Canonica S, Park G-Y, Von Gunten U (2003) Oxidation of pharmaceuticals during ozonation and advanced oxidation processes. Environ Sci Technol 37(5):1016-1024

Huber MM, Gobel A, Joss A, Hermann N, Loffler D, McArdell CS, Ried A, Siegrist H, Ternes TA, vonGunten U (2005) Oxidation of pharmaceuticals during ozonation of municipal wastewater effluents: a pilot study. Environ Sci Technol 39(11):4290-4299

Jobling S, Williams R, Johnson A, Taylor A, Gross-Sorokin M, Nolan M, Tyler CR, van Aerle R, Santos E, Brighty G (2006) Predicted exposures to steroid estrogens in UK rivers correlate with widespread sexual disruption in wild fish populations. Environ Health Perspect 114(Suppl 1):32-39

Johnson AC, Williams RJ (2004) A model to estimate influent and effluent concentrations of estradiol, estrone, and ethinylestradiol at sewage treatment works. Environ Sci Technol 38 (13):3649-3658

Joss A, Keller E, Alder AC, Göbel A, McArdell CS, Ternes T, Siegrist $H$ (2005) Removal of pharmaceuticals and fragrances in biological wastewater treatment. Water Res 39(14):3139-3152

Joss A, Zabczynski S, Gobel A, Hoffmann B, Loffler D, McArdell CS, Ternes TA, Thomsen A, Siegrist H (2006) Biological degradation 
of pharmaceuticals in municipal wastewater treatment: proposing a classification scheme. Water Res 40(8):1686-1696

Kolpin DW, Furlong ET, Meyer MT, Thurman EM, Zaugg SD, Barber LB, Buxton HT (2002) Pharmaceuticals, hormones, and other organic wastewater contaminants in US streams, 1999-2000: a national reconnaissance. Environ Sci Technol 36(6):1202-1211

Kümmerer K (2009a) Antibiotics in the aquatic environment - a reviewpart I. Chemosphere 75(4):417-434

Kümmerer K (2009b) Antibiotics in the aquatic environment - a reviewpart II. Chemosphere 75(4):435-441

Larcher S, Yargeau V (2011) Biodegradation of sulfamethoxazole by individual and mixed bacteria. Appl Microbiol Biotechnol 91 (1):211-218

Larcher S, Delbes G, Robaire B, Yargeau V (2012) Degradation of $17 \alpha$-ethinylestradiol by ozonation-identification of the byproducts and assessment of their estrogenicity and toxicity. Environ Int 39:66-72

Larkin MJ, Kulakov LA, Allen CCR (2005) Biodegradation and Rhodococcus - masters of catabolic versatility. Curr Opin Biotechnol 16(3):282-290

Loonen H, Lindgren F, Hansen B, Karcher W, Niemela J, Hiromatsu K, Takatsuki M, Peijnenburg W, Rorije E, Struij J (1999) Prediction of biodegradability from chemical structure: modeling of ready biodegradation test data. Environ Toxicol Chem 18(8):1763-1768

Martínková L, Uhnáková B, Pátek M, Nesvera J, Kren V (2009) Biodegradation potential of the genus Rhodococcus. Environ Int 35(1):162-177

Miège C, Choubert JM, Ribeiro L, Eusèbe M, Coquery M (2009) Fate of pharmaceuticals and personal care products in wastewater treatment plants - conception of a database and first results. Environ Pollut 157(5):1721-1726

Muller M, Patureau D, Godon JJ, Delgenes JP, Hernandez-Raquet G (2010) Molecular and kinetic characterization of mixed cultures degrading natural and synthetic estrogens. Appl Microbiol Biotechnol 85(3):691-701

O'Grady D, Evangelista S, Yargeau V (2009) Removal of aqueous 17aethinylestradiol by Rhodococcus species. Environ Eng Sci 26 (9):1393-1400

Perez S, Eichhorn P, Aga DS (2005) Evaluating the biodegradability of sulfamethazine, sulfamethoxazole, sulfathiazole, and trimethoprim at different stages of sewage treatment. Environ Toxicol Chem 24(6):1361-1367

Radke M, Lauwigi C, Heinkele G, Murdter TE, Letzel M (2009) Fate of the antibiotic sulfamethoxazole and its two major human metabolites in a water sediment test. Environ Sci Technol 43(9):3135-3141

Rani A, Porwal S, Sharma R, Kapley A, Purohit HJ, Kalia VC (2008) Assessment of microbial diversity in effluent treatment plants by culture dependent and culture independent approaches. Bioresour Technol 99(15):7098-7107

Reinthaler FF, Posch J, Feierl G, Wust G, Haas D, Ruckenbauer G, Mascher F, Marth E (2003) Antibiotic resistance of E. coli in sewage and sludge. Water Res 37(8):1685-1690

Ren YX, Nakano K, Nomura M, Chiba N, Nishimura O (2007) Effects of bacterial activity on estrogen removal in nitrifying activated sludge. Water Res 41(14):3089-3096
Rodayan A, Roy R, Yargeau V (2010) Oxidation products of sulfamethoxazole in ozonated secondary effluent. J Hazard Mater 177:237243

Seviour R, Kragelund C, Kong Y, Eales K, Nielsen J, Nielsen P (2008) Ecophysiology of the Actinobacteria in activated sludge systems. Antonie Van Leeuwenhoek 94(1):21-33

Shi J, Fujisawa S, Nakai S, Hosomi M (2004) Biodegradation of natural and synthetic estrogens by nitrifying activated sludge and ammonia-oxidizing bacterium Nitrosomonas europaea. Water Res 38(9):2323-2330

Ternes TA (1998) Occurrence of drugs in German sewage treatment plants and rivers. Water Res 32(11):3245-3260

Ternes TA, Stuber J, Herrmann N, McDowell D, Ried A, Kampmann M, Teiser B (2003) Ozonation: a tool for removal of pharmaceuticals, contrast media and musk fragrances from wastewater? Water Res 37(8):1976-1982

Ternes T, Janex-Habibi M-L, Knacker T, Kreuzinger N, Siegrist H (2006) Assessment of technologies for the removal of pharmaceuticals and personal care products in sewage and drinking water facilities to improve the indirect potable water reuse (POSEIDON Final ReportEU Research Programme, http://poseidon.bafg.de/servlet/is/2888/)

Vader JS, van Ginkel CG, Sperling FMGM, de Jong J, de Boer W, de Graaf JS, van der Most M, Stokman PGW (2000) Degradation of ethinyl estradiol by nitrifying activated sludge. Chemosphere 41 (8):1239-1243

Vajda AM, Barber LB, Gray JL, Lopez EM, Woodling JD, Norris DO (2008) Reproductive disruption in fish downstream from an estrogenic wastewater effluent. Environ Sci Technol 42(9):3407-3414. doi:10.1021/es0720661

Volkmann H, Schwartz T, Bischoff P, Kirchen S, Obst U (2004) Detection of clinically relevant antibiotic-resistance genes in municipal wastewater using real-time PCR (TaqMan). J Microbiol Methods 56(2):277-286

von Gunten U (2003) Ozonation of drinking water: Part I. Oxidation kinetics and product formation. Water Res 37(7):1443-1467

Weber S, Leuschner P, Kämpfer P, Dott W, Hollender J (2005) Degradation of estradiol and ethinyl estradiol by activated sludge and by a defined mixed culture. Appl Microbiol Biotechnol 67(1):106-112

Wert EC, Rosario-Ortiz FL, Snyder SA (2009) Effect of ozone exposure on the oxidation of trace organic contaminants in wastewater. Water Res 43(4):1005-1014

Yao CCD, Haag WR (1991) Rate constants for direct reactions of ozone with several drinking water contaminants. Water Res 25 (7):761-773

Yargeau V, Huot JC, Rodayan A, Rouleau L, Roy R, Leask RL (2008) Impact of degradation products of sulfamethoxazole on mammalian cultured cells. Environ Toxicol 23(4):7

Yoshimoto T, Nagai F, Fujimoto J, Watanabe K, Mizukoshi H, Makino T, Kimura K, Saino H, Sawada H, Omura H (2004) Degradation of estrogens by Rhodococcus zopfii and Rhodococcus equi isolates from activated sludge in wastewater treatment plants. Appl Environ Microbiol 70(9):5283-5289

Zhang H, Yamada H, Tsuno H (2008) Removal of endocrine-disrupting chemicals during ozonation of municipal sewage with brominated byproducts control. Environ Sci Technol 42(9):3375-3380 